\title{
The interaction between nutritional status and growth hormone in young cattle: differential responsiveness of fat and protein metabolism
}

\author{
Janet M. Dawson ${ }^{1 *}$, Henry M. R. Greathead ${ }^{1}$, Jim Craigon ${ }^{1}$, David L. Hachey ${ }^{2}$, Peter J. Reeds ${ }^{2}$, \\ Jennifer M. Pell ${ }^{3}$ and Peter J. Buttery ${ }^{1}$ \\ ${ }^{1}$ School of Biology, University of Nottingham, Sutton Bonington Campus, Loughborough LE12 5RD, UK \\ ${ }^{2}$ USDA Children's Nutrition Research Center, Baylor College of Medicine, Houston, Texas 77030, USA \\ ${ }^{3}$ Babraham Institute, Babraham, Cambridge CB2 4AT, UK
}

(Received 30 January 1997 - Revised 12 September 1997 - Accepted 24 October 1997)

\begin{abstract}
The effect of dietary intake level on in vivo plasma leucine and plasma palmitate flux rates and on the response to a bolus injection of bovine growth hormone $(\mathrm{GH})$ was investigated in six young steers. Animals were fed on a pelleted diet of dried grass-barley $(0 \cdot 7: 0 \cdot 3, \mathrm{w} / \mathrm{w})$ in quantities sufficient to supply $0.8,1.2,1.6,2.0,2.4$ or $2.65 \times$ maintenance energy requirement, offered in hourly portions. Continuous intravenous infusions of $\left[1-{ }^{13} \mathrm{C}\right]$ leucine or $\left[1-{ }^{13} \mathrm{C}\right]$ palmitate were used to determine the flux of amino acid and fatty acid through the plasma pool before, immediately (1-3 h) after and 22-24 h after a subcutaneous injection of bovine GH $(0.55 \mathrm{mg} / \mathrm{kg}$ body weight). Hourly blood samples were taken for $27 \mathrm{~h}$ to monitor the temporal responses of circulating hormones and metabolites following GH administration. The animal on the lowest plane of nutrition had elevated plasma GH and reduced insulin-like growth factor-1 concentrations compared with those fed on higher intake levels. Plasma leucine flux and leucine concentration increased with intake while palmitate flux and plasma non-esterified fatty acid (NEFA) concentrations were inversely related to intake. Leucine flux rate decreased in the animals fed on the two highest intake levels in response to GH $22-24 \mathrm{~h}$ after administration, but plasma leucine concentrations were reduced in all animals at this time. Only the animal fed on the lowest intake level showed an immediate response to $\mathrm{GH}$ (within $3 \mathrm{~h}$ of administration) with increased palmitate flux and plasma NEFA concentrations but a lipolytic response was apparent in other animals $22-24 \mathrm{~h}$ post-administration although the magnitude of the response was markedly reduced at high intakes. We conclude that lipid and protein metabolism are differentially responsive to $\mathrm{GH}$ and nutritional status.
\end{abstract}

Growth hormone: Palmitate: Leucine: Cattle

The partitioning of nutrients between lean and fat deposition is an area of great current interest in farm livestock production. Nutritional status has a marked influence on nutrient utilization and body composition which is at least partly modulated through changes in the endocrine status of the animal. The role of growth hormone (GH) in the control of animal growth is well documented. It has somatogenic or metabolic effects on a multitude of tissues and is a homeorhetic regulator of the postabsorptive use of nutrients. Its use in animal production has focused on its influence in effecting changes in the partitioning of nutrients between muscle and fat in response to exogenous administration resulting in improved lean : fat ratios. The anabolic effects of $\mathrm{GH}$ on muscle are believed to be largely mediated by insulin-like growth factor-1 (IGF1) which stimulates protein synthesis (Douglas et al. 1991) while the effects of $\mathrm{GH}$ on adipose tissue are thought to be mediated directly by binding to $\mathrm{GH}$ receptors on the adipocyte membrane. The magnitude of the response to exogenous GH administration is variable and at least partly attributable to nutritional status. An interaction between nutritional status and plasma concentrations of $\mathrm{GH}$ and IGF-1 has been recognized in many species including man, dogs and cattle whereby $\mathrm{GH}$ concentrations become

\footnotetext{
Abbreviations: GH, growth hormone; HFBA, heptafluorobutyric anhydride; IGF-1, insulin-like growth factor-1; ME, metabolizable energy; NEFA, nonesterified fatty acids; PFB, pentafluorobenzyl.

* Corresponding author: Dr Janet Dawson, fax +44 (0) 1159516122 , email Janet.Dawson@nottingham.ac.uk
} 
elevated and IGF-1 levels are reduced by starvation or low nutritional intakes (see Breier \& Sauerwein, 1995). Exogenous administration of $\mathrm{GH}$ to animals on high and low planes of nutrition has been shown to stimulate a rise in plasma IGF-1 concentration only in well-fed animals (Breier et al. 1988) suggesting that the GH-IGF-1 axis is uncoupled in malnourished animals. The mechanism responsible for the reduced plasma IGF-1 concentrations in nutritionally-deprived animals is not fully understood but has been suggested to involve a reduction in the number or affinity of hepatic GH receptors (see Breier \& Sauerwein, 1995 ) or to be due to low plasma insulin, glucose or amino acid concentrations which affect hepatic IGF-1 transcription rates (Kriel et al. 1992) or IGF-1 mRNA stability (Thissen et al. 1991). The level of nutrition required for the GH-IGF-1 axis to remain coupled has not been defined, nor has the response to exogenous $\mathrm{GH}$ on whole-body protein and lipid metabolism at different nutritional intakes been fully established.

Most studies investigating the effect of nutritional status on protein and lipid metabolism have used extremes of intake to magnify any metabolic differences between groups. The aim of the present study was to investigate the effect of a range of dietary intake levels (from submaintenance to ad libitum) on in vivo plasma leucine and plasma palmitate flux rates and to determine the effect of a single bolus injection of bovine GH on these flux rates, both immediately (after $1-3 \mathrm{~h}$ ) and after 22-24h, when total plasma IGF- 1 concentrations would be expected to be elevated, if the GH-IGF-1 axis were coupled. This approach of using graded feed intake levels was taken in order to determine whether the pattern of whole-body protein and lipid metabolism is similar at all intakes, or whether $\mathrm{N}$ and lipid metabolism demonstrate different sensitivities to nutrient intake and whether this affects the response to endocrinological stimulation. Preliminary results of this study have been published previously (Dawson et al. 1993b).

\section{Materials and methods}

\section{Animals, diets and treatments}

Six Hereford $\times$ Friesian steers (approximately 168 (SE 18) $\mathrm{kg}$ ) were individually penned and fed on a pelleted diet of dried grass and barley $(0.7: 0.3, \mathrm{w} / \mathrm{w})$. The diet contained $890 \mathrm{~g} \mathrm{DM} / \mathrm{kg}$ fresh weight, $192 \mathrm{~g}$ crude protein $(\mathrm{N} \times 6.25)$ and $18.9 \mathrm{MJ}$ gross energy $/ \mathrm{kg} \mathrm{DM}$ and had minerals (Wrightmin beef minerals, Ashbourne, Derby., UK) added at $25 \mathrm{~g} / \mathrm{kg}$. The metabolizable energy (ME) content was estimated from the chemical analysis to be $11.6 \mathrm{MJ} / \mathrm{kg} \mathrm{DM}$ (Agricultural and Food Research Council, 1993). The ME requirements of the animals were calculated using the equation:

$\mathrm{ME}$ required for maintenance $(\mathrm{MJ} / \mathrm{d})$

$$
=\frac{(\text { live weight } \times 0.061)+5.67}{\mathrm{k}_{\mathrm{m}}},
$$

where $k_{\mathrm{m}}$ is the efficiency with which $\mathrm{ME}$ is used for maintenance and was assumed to be 0.72 (Agricultural and Food Research Council, 1993).

Animals were fed at $2.4 \times$ maintenance for 6 weeks before being randomly allocated at approximately 24 weeks of age to one of six different dietary feeding levels: $0.8,1.2$, $1.6,2.0,2.4$ or $2.8 \times$ maintenance. Average animal live weight at this time was 206 (SE 26) $\mathrm{kg}$. After 1 week of feeding at the assigned intake level with the food being given in two equal portions ( 08.30 and 17.00 hours) the animals were transferred to metabolism cages and gradually introduced to an hourly feeding regimen. After 1 week, sterile polyurethane catheters $(1.2 \mathrm{~mm}$ internal diameter; British Viggo, Swindon, Wilts., UK) were inserted into both jugular veins and kept patent with sterile heparinized saline $(37.5$ units $/ \mathrm{ml})$. The left infusion catheter and the right sampling catheter were 300 and $200 \mathrm{~mm}$ long respectively.

Animals were weighed before being assigned to their appropriate intake level and again before being transferred to the metabolism cage. The amount of feed given was adjusted to their increase in weight and this feed supply was then maintained throughout the time they were in metabolism cages. Any refused food was removed daily and weighed. Animals had free access to water at all times.

Each animal received a total of four intravenous infusions: two of $\left[1-{ }^{13} \mathrm{C}\right]$ leucine given on consecutive days and two of $\left[1-{ }^{13} \mathrm{C}\right]$ palmitate given on consecutive days, the order of the leucine and palmitate infusions being randomly assigned and separated by 1 week. Four of the animals subsequently received another four infusions, as previously, 5 weeks later, whilst being fed at $2.0 \times$ maintenance intake (see later).

\section{Preparation of infusates}

$\left[1-{ }^{13} \mathrm{C}\right]$ leucine $\left(5.2 \mathrm{mg} / \mathrm{kg}\right.$ body weight; 99.3 atom $\%{ }^{13} \mathrm{C}$; Tracer Technologies, Somerville, MA, USA) was dissolved in $1300 \mathrm{ml}$ saline $(0.15 \mathrm{~mol} / \mathrm{l})$ and filter sterilized $(0.22 \mu \mathrm{m})$. This was sufficient for the two consecutive infusions, a total of $13 \mathrm{~h}$, when infused at approximately $100 \mathrm{ml} / \mathrm{h}$ (equivalent to approximately $3 \mu \mathrm{mol} / \mathrm{kg}$ body weight per h). A priming dose of $3.0 \mu \mathrm{mol} / \mathrm{kg}$ body weight in a total volume of $20 \mathrm{ml}$ saline was also prepared for each infusion and filter sterilized $(0.22 \mu \mathrm{m})$.

$\left[1-{ }^{13} \mathrm{C}\right]$ palmitic acid $(7.8 \mathrm{mg} / \mathrm{kg}$ body weight: 99 atom $\%$ ${ }^{13} \mathrm{C}$; Tracer Technologies) was dissolved in $\mathrm{n}$-hexane, reacted with methanolic $\mathrm{KOH}$ at $60^{\circ}$ to form the $\mathrm{K}$ salt and bound to sterile bovine serum albumin (Fraction V; Sigma Chemical Co., Poole, Dorset, UK) in a molar ratio of $3.9: 1$ as described by Wolfe (1992). A total volume of $1300 \mathrm{ml}$ was prepared for each animal, sufficient for the two consecutive infusions when infused at approximately $100 \mathrm{ml} / \mathrm{h}$ (which was equivalent to approximately $2 \cdot 3 \mu \mathrm{mol} / \mathrm{kg}$ body weight per $\mathrm{h}$ ).

Recombinant bovine GH (Somidobove; Lilly Research Centre Ltd, Surrey, UK) was dissolved in saline $(0.15 \mathrm{~mol} / \mathrm{l})$ immediately before use and filter sterilized $(0.22 \mu \mathrm{m})$ before administration. 


\section{Experimental procedure}

At $2 \mathrm{~d}$ after the animals were cannulated, the first intravenous infusion of either $\left[{ }^{13} \mathrm{C}\right]$ leucine or $\left[{ }^{13} \mathrm{C}\right]$ palmitate was commenced (see earlier). The infusates were administered by peristaltic pump (Minipuls 2, Gilson, France) at a rate of approximately $1.6 \mathrm{ml} / \mathrm{min}$, the exact rate being determined for each animal from the difference in weight of the infusate over each infusion period.

Blood samples $(10 \mathrm{ml}, n 3)$ were taken at $10 \mathrm{~min}$ intervals before the start of each infusion for determination of background isotopic enrichment. Immediately before the leucine infusions commenced, the sterile priming doses of $\left[1-{ }^{13} \mathrm{C}\right]$ leucine were administered via syringes directly into the left jugular cannula over a $5 \mathrm{~min}$ period. The primed infusion lines were then connected to the cannula and the infusion continued. Blood samples were taken from the right cannula at $30 \mathrm{~min}$ intervals for the first $2 \mathrm{~h}$ and at 20 min intervals thereafter. Samples taken for determination of plasma isotopic enrichment were collected into tubes containing either 250 units heparin (leucine infusions) or $150 \mu \mathrm{g}$ K-EDTA (palmitate infusions), mixed by inversion and stored on ice. Plasma was separated by centrifugation at $1000 \mathrm{~g}$ for $15 \mathrm{~min}$ and stored at $-80^{\circ}$ until analysed.

The first infusions of $\left[1-{ }^{13} \mathrm{C}\right]$ leucine or $\left[1-{ }^{13} \mathrm{C}\right]$ palmitate were continued for $5 \mathrm{~h}$. Bovine $\mathrm{GH}(0.55 \mathrm{mg} / \mathrm{kg}$ body weight) was then administered by subcutaneous injection into the brisket and the infusion continued for another $3 \mathrm{~h}$. The infusions were then terminated. The following day, $19 \mathrm{~h}$ after the $\mathrm{GH}$ was administered, the infusions (primed where appropriate) were recommenced, using the same infusate as the previous day and continued for $5 \mathrm{~h}$. Blood samples ( $n$ 3) were again taken at $10 \mathrm{~min}$ intervals immediately before re-commencement of the infusion to establish background isotopic enrichments and at 20$30 \mathrm{~min}$ intervals throughout the infusion as before. Additional blood samples $(5 \mathrm{ml})$ were taken from each animal at hourly intervals beginning $2 \mathrm{~h}$ after the commencement of the first infusion ( $3 \mathrm{~h}$ before the $\mathrm{GH}$ was administered) and continuing for $27 \mathrm{~h}$ until the second infusion was terminated $(24 \mathrm{~h}$ post-GH). These samples were collected into tubes containing 250 units heparin regardless of the isotope being infused and the plasma, separated as described earlier, was stored at $-40^{\circ}$ until analysed for hormone and metabolite concentrations. After 1 week the infusions were repeated using the other ${ }^{13} \mathrm{C}$-labelled metabolite.

In order that any observed changes in flux rate could be directly attributed to the effect of the GH administration, the infusions were subsequently repeated 5 weeks later on four of the animals over the same time period, without $\mathrm{GH}$ administration. These animals were all fed at the same intake level $(2 \times$ maintenance) and consequently can be used to obtain an estimate of the extent of variation between animals (see statistical analysis). These animals were maintained at this intake level for 4 weeks before measurements of flux were made. Each animal was infused with either $\left[1-{ }^{13} \mathrm{C}\right]$ leucine or $\left[1-{ }^{13} \mathrm{C}\right]$ palmitate for $8 \mathrm{~h}$. The infusion was then terminated and re-commenced $16 \mathrm{~h}$ later for further $5 \mathrm{~h}$. Blood samples were taken hourly for $27 \mathrm{~h}$ as before, for analysis of hormone and metabolite concentrations, beginning $2 \mathrm{~h}$ after the start of the first infusion and continuing until the end of the second infusion. After 1 week, the infusions were repeated using the other ${ }^{13} \mathrm{C}$ labelled metabolite.

\section{Analytical methods}

Measurement of plasma $\int^{13}$ CJleucine enrichment. LLeucine-methyl-d3 (98\% D; Cambridge Isotope Laboratories, Woburn, MA, USA) was added to all plasma samples as an internal standard. Free amino acids were isolated from $0.5 \mathrm{ml}$ plasma samples on a cation exchange resin (Biorad AG 50W-X8; 100-200 mesh, $\mathrm{H}^{+}$form) and eluted with $3 \mathrm{M}-\mathrm{NH}_{4} \mathrm{OH}$. The samples were esterified to n-propyl esters and heptafluorobutyric anhydride (HFBA) derivatives were prepared as described by Berthold et al. (1991) and stored in $1.0 \mathrm{ml}$ ethyl acetate at $-20^{\circ}$ until analysed.

Mass spectrometric analyses were performed on a Hewlett-Packard 5988A GC-mass spectrometer equipped with an HP-5980 GC (Hewlett-Packard Co., Palo Alto, CA, USA). GC separation of the HFBA-amino acid esters was effected on a $30 \mathrm{~m} \times 0.32 \mathrm{~mm}$ DB-5 column ( $\mathrm{J} \& \mathrm{~W}$ Scientific Co., Rancho Cordova, CA, USA) with a temperature gradient from 80 to $150^{\circ}$ at $10^{\circ} / \mathrm{min}$ and a flow rate of $2.4 \mathrm{ml} / \mathrm{min}$ with a split ratio of $6: 1$. The retention time of leucine under these conditions was $5.7 \mathrm{~min}$. Oven temperatures were raised to $300^{\circ}$ after sample elution and held for $2 \mathrm{~min}$ to prevent build up of contaminants on the column from previous injections. Negative chemical ionization was performed with $\mathrm{CH}_{4}$ as the reagent gas. Selected ion monitoring was performed on ions $\mathrm{m} / \mathrm{z}$ 349/350/352.

Measurement of plasma $\left[{ }^{13}\right.$ Clpalmitate enrichment. Plasma palmitate was derivatized to its pentafluorobenzyl (PFB) ester by the method of Hachey et al. (1991). GC separation of the PFB esters was performed on a $30 \mathrm{~m}$ $\times 0.25 \mathrm{~mm}$ SP-2330 column (Supelco Inc., Bellefonte, PA, USA) with a column flow rate of $0.7 \mathrm{ml} / \mathrm{min}$ and a split ratio of $25: 1$. The temperature was programmed from 150 to $250^{\circ}$ at $10^{\circ} / \mathrm{min}$. The retention time of the palmitate under these conditions was $9.3 \mathrm{~min}$. Negative chemical ionization was performed with $\mathrm{CH}_{4}$ as the reagent gas. Selected ion monitoring was performed for masses $\mathrm{m} / \mathrm{z}$ $255 / 256$.

Plasma hormone and metabolite concentrations. Plasma GH concentrations were measured in the twenty-seven hourly samples by double antibody radioimmunoassay as described by Tindal et al. (1985). Plasma IGF-1 concentrations were determined in the same samples by radioimmunoassay after acid-ethanol extraction (Pell \& Bates, 1992). Plasma insulin concentrations were measured by radioimmunoassay kit (Medgenix Ltd, High Wycombe, Bucks., UK) while glucose and urea-N concentrations were determined colorimetrically as described previously (Dawson et al. 1993a). As heparin interferes with the determination of non-esterified fatty acid (NEFA) concentrations, these measurements were made on plasma samples taken during the palmitate infusions using the Wako 


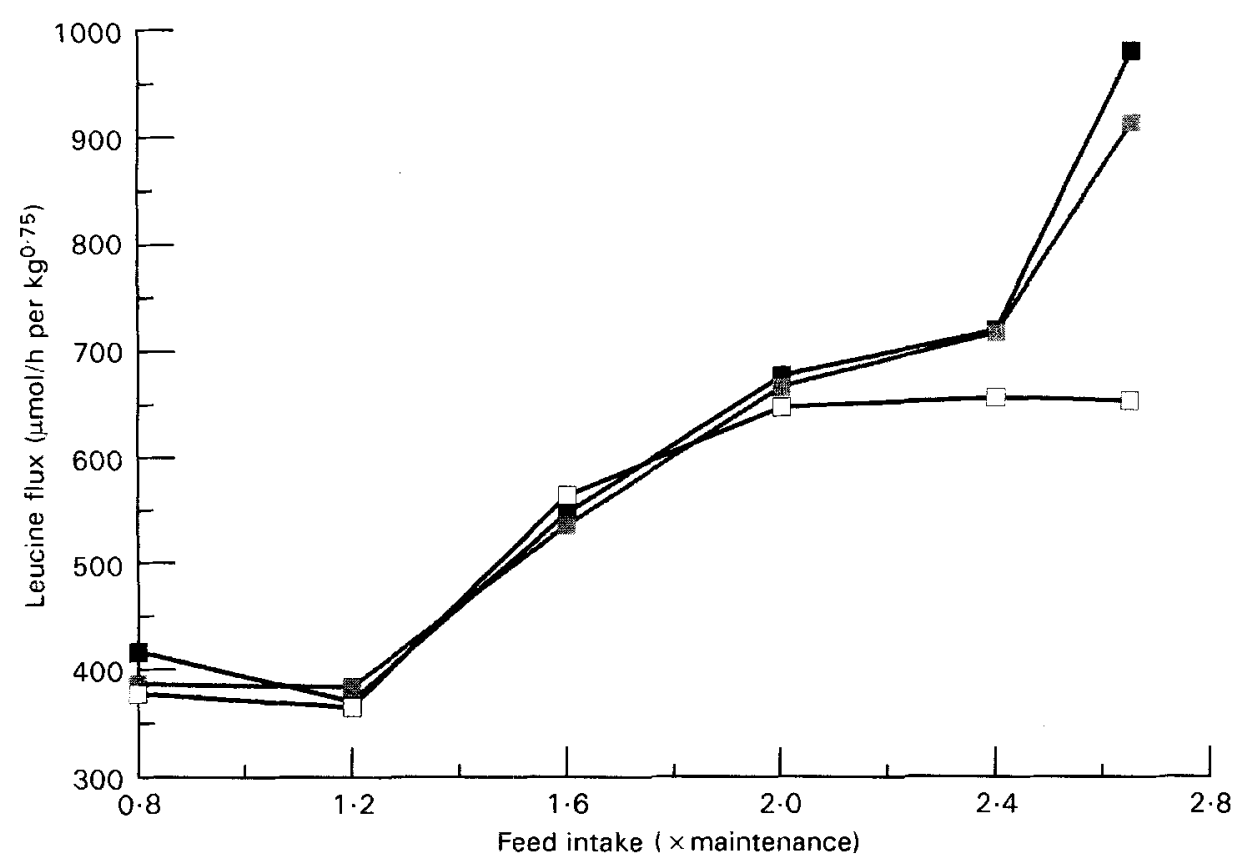

Fig. 1. Effect of feed intake on plasma leucine flux and the response to growth hormone (GH) administration in young cattle. Values are raw data for plasma leucine flux rates for one animal fed at each intake level between 0.8 and $2.65 \times$ maintenance, before $\mathrm{GH}$ administration $(\square)$, 1-3h after administration ( $⿴)$ and 22-24h after GH administration ( $\square$ ). Significant effects of intake level $(P=0.013)$, time $(P<0.05)$ and time $\times$ intake $(P<0.05)$ were detected. Standard errors of difference between points based on the deviation about the best fitted quadratic trends were $89 \mu \mathrm{mol} / \mathrm{h}$ per $\mathrm{kg}^{0.75}$ for comparing points based on the same line and $51 \mu \mathrm{mol} / \mathrm{h} \mathrm{per} \mathrm{kg}^{0.75}$ for comparing points at the same intake level. These errors were smaller than those obtained in a subsequent experiment $\left(169\right.$ and $87 \mu \mathrm{mol} / \mathrm{h}$ per kg $\left.{ }^{0.75}, 3 \mathrm{df}\right)$ for between-and within-animal variation respectively when the infusions were repeated on four of the animals all fed at the same intake level $(2 \times$ maintenance) but without $\mathrm{GH}$ administration, which supports the assumption that the deviations from the fitted trends contained only random error.

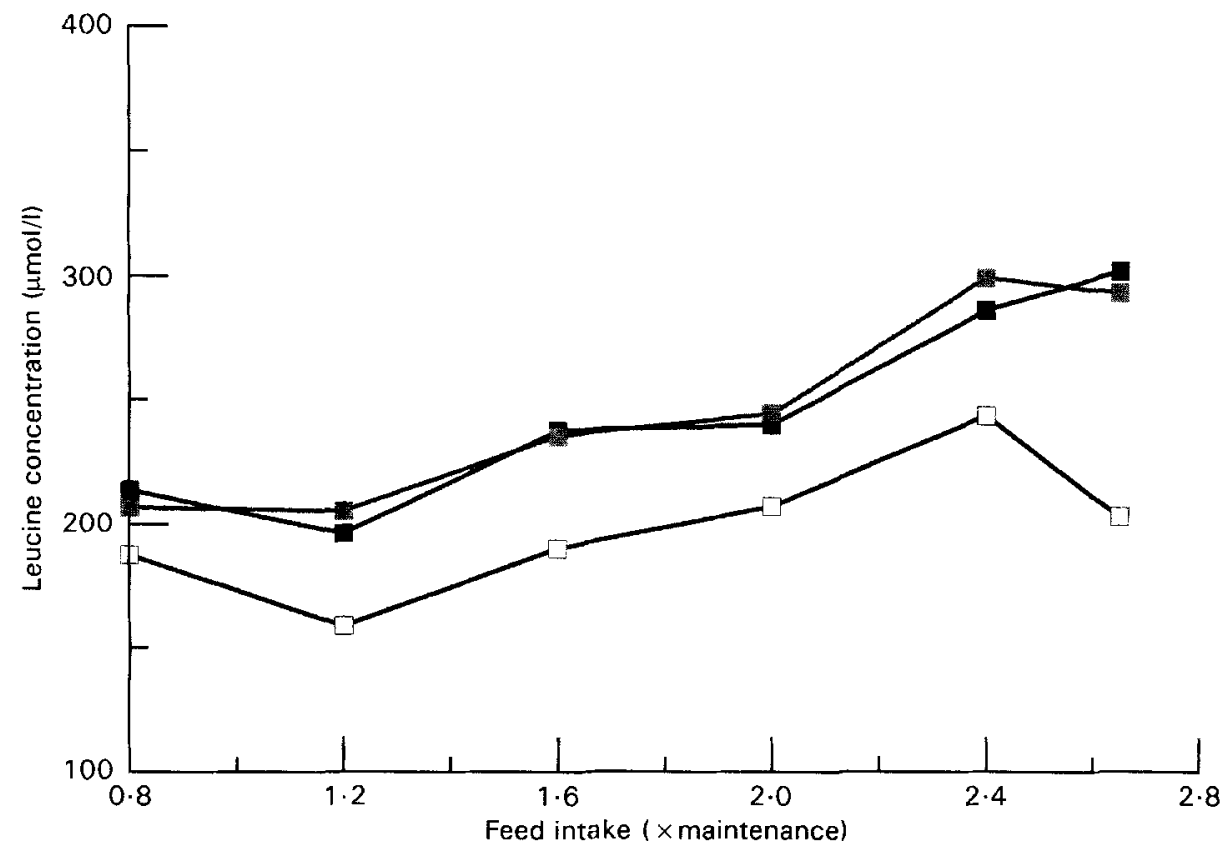

Fig. 2. Effect of feed intake on plasma leucine concentrations and the response to growth hormone (GH) administration in young cattle. Values are raw data for plasma leucine concentrations for one animal fed at each intake level between 0.8 and $2.65 \times$ maintenance, before GH

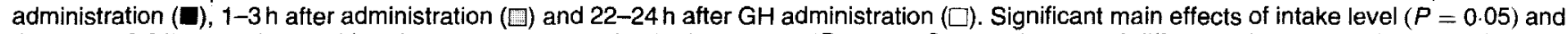
time $(P<0.01)$ were detected but there was no time $\times$ intake interaction $(P>0.1)$. Standard errors of difference between points based on the deviation about the best fitted quadratic trends were $27 \mu \mathrm{mol} / \mathrm{I}$ for comparing points based on the same line and $17 \mu \mathrm{mol} / \mathrm{l}$ for comparing points at the same intake level. These errors were smaller than those obtained in a subsequent experiment ( 44 and $26 \mu \mathrm{mol} / \mathrm{l}, 3 \mathrm{df}$ ) for between- and within-animal variation respectively when the infusions were repeated on four of the animals all fed at the same intake level ( $2 \times$ maintenance) but without GH administration, which supports the assumption that the deviations from the fitted trends contained only random error. 


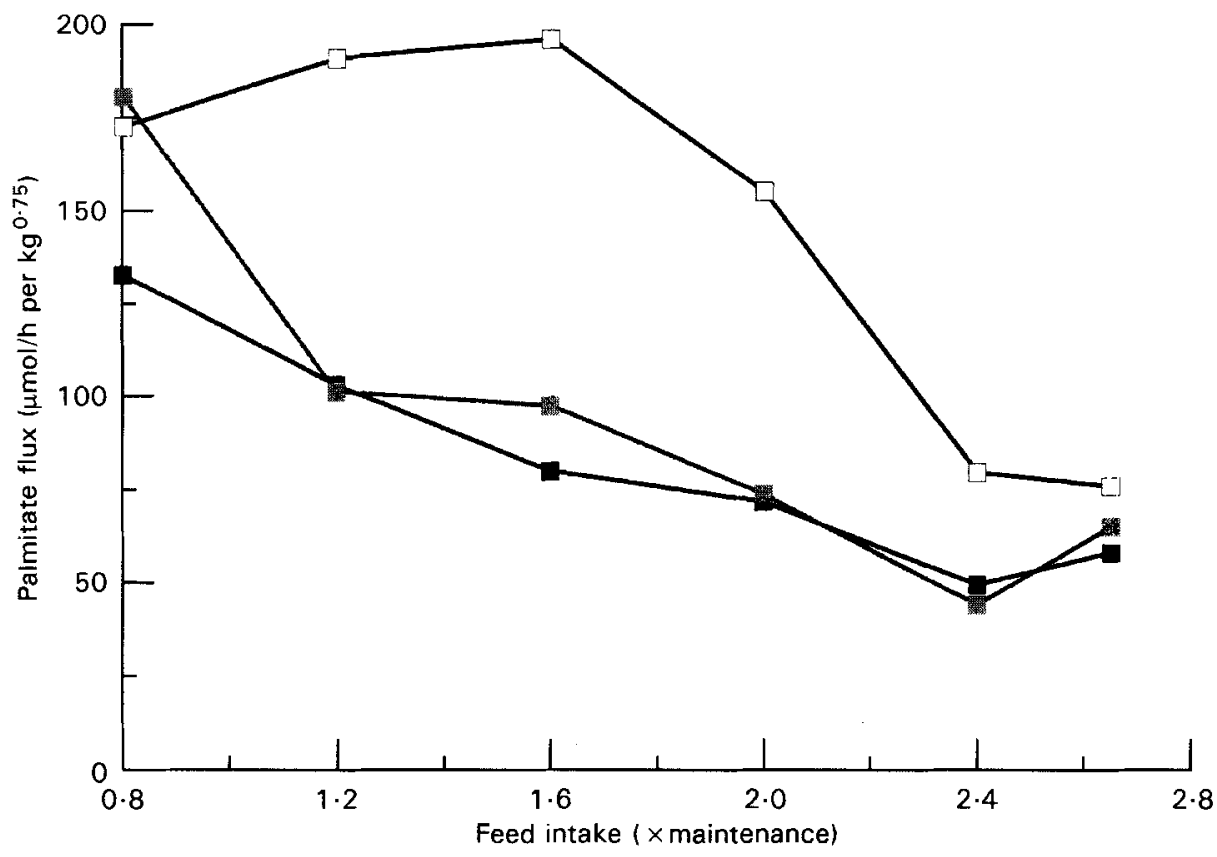

Fig. 3. Effect of feed intake on plasma palmitate flux and the response to growth hormone (GH) administration in young cattle. Values are raw data for plasma palmitate flux rates for one animal fed at each intake level between 0.8 and $2.65 \times$ maintenance, before $\mathrm{GH}$ administration ( $\square$ ), $1-3 \mathrm{~h}$ after administration ( $(0)$ and 22-24 h after GH administration ( $\square)$. Significant main effects of intake level $(P=0.012)$, time $(P<0.001)$ and time $\times$ intake $(P=0.005)$ were detected. Standard errors of difference between points based on the deviation about the best fitted quadratic trends were $21 \mu \mathrm{mol} / \mathrm{h}$ per kg $\mathrm{kg}^{0.75}$ for comparing points based on the same line and $16 \mu \mathrm{mol} / \mathrm{h}$ per $\mathrm{kg}^{0.75}$ for comparing points at the same intake level. These errors were smaller than those obtained in a subsequent experiment (29 and $25 \mu \mathrm{mol} / \mathrm{h}$ per $\left.\mathrm{kg}^{0.75}, 3 \mathrm{df}\right)$ for between- and withinanimal variation respectively when the infusions were repeated on four of the animals all fed at the same intake level $(2 \times$ maintenance) but without GH administration, which supports the assumption that the deviations from the fitted trends contained only random error.

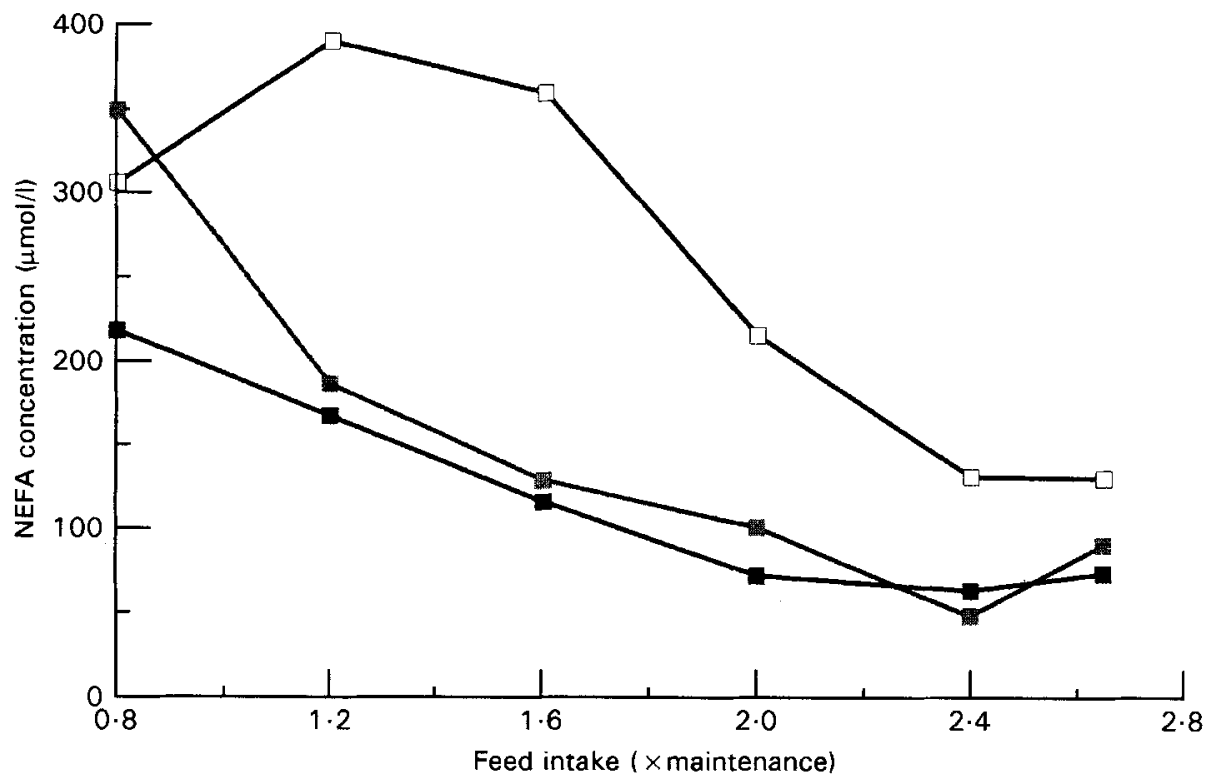

Fig. 4. Effect of feed intake on serum non-esterified fatty acid (NEFA) concentrations and the response to growth hormone (GH) administration in young cattle. Values are raw data for plasma NEFA concentrations for one animal fed at each intake level between 0.8 and $2.65 \times$ maintenance, before $\mathrm{GH}$ administration ( $\square$ ), 1-3h after administration (四) and 22-24h after GH administration ( $\square$ ). Significant main effects of intake level $(P=0.006)$, time $(P<0.05)$ and time $\times$ intake $(P<0.05)$ were detected. Standard errors of difference between points based on the deviation about the best fitted quadratic trends were $48 \mu \mathrm{mol} / \mathrm{l}$ for comparing points based on the same line and $47 \mu \mathrm{mol} / \mathrm{l}$ for comparing points at the same intake level. Similar errors (51 and $39 \mu \mathrm{mol} / \mathrm{l}, 3 \mathrm{df}$ ) were found for between- and within-animal variation respectively in a subsequent experiment when the infusions were repeated on four of the animals all fed at the same intake levels ( $2 \times$ maintenance) but without GH administration, supporting the assumption that the deviations from the fitted trends contained only random error. 
NEFA-C test kit (Alpha Laboratories, Eastleigh, Hants, UK). It is acknowledged that palmitate from the infusion will make some contribution to the NEFA concentration measured.

\section{Calculations and statistical analysis}

Plasma flux rates were calculated from the tracer:tracee ratios of leucine and palmitate which were determined by matrix calculation of the mole fractions of the natural abundance and ${ }^{13} \mathrm{C}$-labelled ions for each of the isotopes. Plasma flux rates were then calculated from the infusion rate of the isotope divided by the tracer : tracee ratios. Flux rates were expressed relative to metabolic body weight $\left(\mathrm{kg}^{0.75}\right)$ of the animals.

Preliminary studies had shown that plasma plateau enrichments of both $\left[{ }^{13} \mathrm{C}\right]$ leucine and $\left[{ }^{13} \mathrm{C}\right]$ palmitate were attained within $2 \mathrm{~h}$ of commencement of the infusions. For each animal and each infusion, two background samples (pre-infusion) and four samples taken at plateau (between 2 and $5 \mathrm{~h}$ of infusion) were analysed for determination of flux rate. The acute response to GH was determined in four samples taken during the $3 \mathrm{~h}$ following $\mathrm{GH}$ administration (5-8h infusion) while the delayed response to GH was determined in four samples taken at plateau during the second infusion $(22-24 \mathrm{~h}$ post-GH). These data were analysed using the Genstat 5 statistical package (Digby et al. 1989) to determine the effect of intake, the response to $\mathrm{GH}$ (immediate or delayed) and interactions between the response to $\mathrm{GH}$ with intake (time $\times$ intake). A repeated measure split-plot ANOVA with animals as the main plot and times within animals as the sub-plot factor was used, the degrees of freedom for the within-animal $F$ tests being adjusted to account for the correlation between repeated measures on the same animal (Winer et al. 1991). The variation between animals was analysed by fitting linear and quadratic trends to the intake data. The deviations about the trends in each period, pooled over all three periods, were used as error for the within-animal comparison and the deviations of the animal means from the overall trend were used as the between-animal error. The deviations about the trends were also used as the basis of the within-animal variance-covariance matrix between periods from which the repeated measure factor (Greenhouse-Geisser epsilon) for adjusting the degrees of freedom (Winer et al. 1991) was calculated. An estimate of the variation between animals and between the infusions was also obtained from the second experiment when the infusions were repeated on four of the animals all fed at the same intake level $(2 \times$ maintenance) but without $\mathrm{GH}$ administration. These errors are given in the legends to Figs. 1-4.

The twenty-seven hourly blood samples were assayed individually and the mean hormone and metabolite concentrations were then calculated for the following three time intervals: before $\mathrm{GH}$ administration, $1-3 \mathrm{~h}$ post-GH and $22-24 \mathrm{~h}$ post-GH ( $n 3$ per interval). Plasma NEFA concentrations were averaged for the periods before $\mathrm{GH}$ administration ( $n$ 9), 1-3 h post-GH $(n 9)$ and $22-24 \mathrm{~h}$ post$\mathrm{GH}(n 9)$. These data were then subjected to analysis as previously to determine the effect of intake and response to $\mathrm{GH}$ and time $\times$ intake interactions.

\section{Results}

The animal fed at the highest intake (projected to be $2.8 \times$ maintenance) did not reach its target level due to some feed refusals and its actual intake level was $2.65 \times$ maintenance. Animals on the lower intake levels consumed all the feed offered. Weights of the animals at the end of the second week of infusions when they were removed from the metabolism crates indicated that those fed at intake levels of $1.6 \times$ maintenance and above gained body weight over the duration of the trial $(+4$ to $+11.5 \mathrm{~kg})$ while those fed below this level lost body weight $(-12$ to $-16 \mathrm{~kg})$.

\section{Plasma enrichment of $\left[{ }^{13}\right.$ Clleucine}

The effect of intake and the response to exogenous $\mathrm{GH}$ administration on plasma leucine flux rate are shown in Fig. 1. Basal flux rate increased with level of feed intake from approximately 400 to $980 \mu \mathrm{mol} / \mathrm{h}$ per $\mathrm{kg}^{0.75}$ (linear trend $P<0.01)$. There was a significant $(P<0.05)$ time $\times$ intake interaction with evidence that the pattern of response to $\mathrm{GH}$ differed with intake in both linear and quadratic terms. This was due to the fact that in animals fed at low intake levels there appeared to be no effect of $\mathrm{GH}$ on plasma leucine flux but at intakes above $2 \times$ maintenance, $22-24 \mathrm{~h}$ after GH administration, plasma flux rates appeared to plateau at approximately $650 \mu \mathrm{mol} / \mathrm{h}$ per $\mathrm{kg}^{\mathrm{g}}{ }^{.75}$. This meant that compared with animals on lower intakes, the animal on the highest intake level showed a decrease in leucine flux of $30 \%$ in response to $\mathrm{GH}$.

Plasma leucine concentrations before and after administration of GH are shown in Fig. 2. As with leucine flux rate, plasma leucine concentrations also increased with intake from approximately 200 to $300 \mu \mathrm{mol} / 1$ (overall linear trend, $P=0.024)$. There was a significant $(P<0.01)$ effect of time as a result of GH administration as plasma concentrations were considerably reduced in all animals at the time of the second infusion of tracer $(22-24 \mathrm{~h}$ after $\mathrm{GH}$ ) compared with before $\mathrm{GH}$ and immediately $(0-3 \mathrm{~h})$ after its administration. There was a suggestion that the linear response differed between periods $(P<0.1)$ which was due to the fact that there appeared to be a greater decline in plasma leucine concentration in animals fed at the higher intake levels than those at the lower intakes, such that the difference in plasma concentrations between the two extreme intake levels was only $15 \mu \mathrm{mol} / 122-24 \mathrm{~h}$ after GH administration compared with almost $90 \mu \mathrm{mol} / \mathrm{l}$ before.

\section{Plasma enrichment of $I^{13}$ Clpalmitate}

The effects of intake and GH administration on plasma palmitate flux rate are shown in Fig. 3. Basal plasma palmitate flux rates were highest in the most poorly-fed animal $\left(132 \mu \mathrm{mol} / \mathrm{h}\right.$ per $\left.\mathrm{kg}^{0.75}\right)$ and decreased with intake to approximately $50 \mu \mathrm{mol} / \mathrm{h}$ per $\mathrm{kg}^{0.75}$ at the two highest intake levels (overall linear trend, $P=0.005$ ). There was a 
significant effect of time $(P<0.001)$ indicating that the average flux at the three time points was different and a significant $(P=0.005)$ time $\times$ intake interaction with evidence that the quadratic response differed between periods $(P=0.002)$ as a result of $\mathrm{GH}$ administration. This was due to the most poorly-fed animal showing an immediate increase in plasma palmitate flux rate $35 \%$ increase within $3 \mathrm{~h}$ of administration) which was maintained for $24 \mathrm{~h}$, while animals on intake levels above maintenance showed no acute response to GH but all had elevated palmitate flux rates $22-24 \mathrm{~h}$ after administration. The magnitude of the response to $\mathrm{GH}$ varied with intake, the animal fed at $1.6 \times$ maintenance showing greatest stimulation of palmitate flux in response to $\mathrm{GH}$ administration ( $148 \%$ increase) while animals fed at higher intake levels showed markedly decreased levels of stimulation (only $30 \%$ at $2.65 \times$ maintenance). Serum NEFA concentrations reflected the changes in palmitate flux with intake (linear trend $P=0.003$ ), with basal concentrations ranging from $230 \mu \mathrm{mol} / 1$ in the most poorly-fed animal and decreasing with intake to $60 \mu \mathrm{mol} / 1$ at the highest intake level (Fig. 4). Again, a significant $(P<0.01)$ overall effect of time and a significant $(P<0.05)$ time $\times$ intake interaction was detected with evidence that the quadratic trend was different $(P<0.05)$ after $\mathrm{GH}$ administration. As with palmitate flux rate, only the most poorly-fed animal showed an immediate response to $\mathrm{GH}$ with a $55 \%$ increase in serum NEFA concentration within $3 \mathrm{~h}$ of administration and was still elevated to a similar extent $24 \mathrm{~h}$ after administration. Animals fed at all other intakes showed a delayed increase in serum NEFA concentration in response to the $\mathrm{GH}(22-24 \mathrm{~h}$ after administration), with the response again being greater in the animals fed at low intakes (180$200 \%$ increase in animals fed at 1.6 and $2.0 \times$ maintenance, compared with $100 \%$ increase in the animal fed at $2.65 \times$ maintenance). The stimulation of lipolysis by $\mathrm{GH}$ was markedly less in the well-fed animals. No effect was seen immediately ( $1-3 \mathrm{~h}$ ) after the GH injection in these animals.

\section{Plasma hormone and metabolite concentrations}

Basal plasma concentrations of GH, IGF-1, insulin, glucose and urea in the six animals fed at different intake levels are shown in Fig. 5(a) and the concentration changes in response to $\mathrm{GH}$ at the time the leucine and palmitate flux measurements were made (i.e. $1-3 \mathrm{~h}$ and $22-24 \mathrm{~h}$ post-GH) are shown in Figs. 5(b) and 5(c) respectively.

Basal plasma GH concentrations (Fig. 5(a)) were low in all animals and close to, or below, assay detection limits $(<0.1 \mathrm{ng} / \mathrm{ml}$ ) for most of the well-fed animals but were slightly higher in those fed close to maintenance (2$5 \mathrm{ng} / \mathrm{ml}$ ). On administration of the $\mathrm{GH}$, plasma concentrations increased rapidly in all animals (within $1 \mathrm{~h}$; results not shown) and reached the highest concentrations (about $200 \mathrm{ng} / \mathrm{ml}$ ) in the poorly-fed animals (Fig. 5(b)). Maximal concentrations were generally attained within the first $3 \mathrm{~h}$ after administration and declined thereafter but remained elevated at the time of the second flux measurement (22$24 \mathrm{~h}$ post-GH; Fig. $5(\mathrm{c})$ ). The rate of decline tended to be slower in the poorly-fed animals suggesting that the metabolic clearance rate was reduced in these animals. Plasma GH concentrations at the time of the second flux measurement $(22-24 \mathrm{~h}$ after $\mathrm{GH}$ administration) thus ranged from $43 \mathrm{ng} / \mathrm{ml}$ in the animal eating $0.8 \times$ maintenance to $10 \mathrm{ng} / \mathrm{ml}$ in the well-fed animals. Overall there was evidence of a linear response to intake $(P=0.078)$ and a significant $(P<0.001)$ effect of time indicating that there were differences in the average plasma concentration at each of the three time intervals measured as a result of $\mathrm{GH}$ administration. There was also evidence of a time $\times$ intake interaction $(P<0.1)$ which differed in the quadratic response, presumably due to the greater response of the most poorly-fed animal to $\mathrm{GH}$.

Basal plasma IGF-1 concentrations increased with level of intake from $50 \mathrm{ng} / \mathrm{ml}$ at $0.8 \times$ maintenance to $190 \mathrm{ng} / \mathrm{ml}$ at $2.4 \times$ maintenance and then plateaued (Fig. 5(a)). Administration of $\mathrm{GH}$ increased plasma IGF-1 concentrations at all intake levels but the response was gradual and maximal concentrations were not reached until 22-24h after $\mathrm{GH}$ was administered. There was little effect on plasma IGF-1 concentrations within the first $3 \mathrm{~h}$ after $\mathrm{GH}$ administration (Fig. 5(b)) but at the time of the second flux measurement (22-24 h post-GH) plasma IGF-1 concentrations were elevated in all animals by $100-250 \mathrm{ng} / \mathrm{ml}$ compared with before $\mathrm{GH}$ administration, the greatest increase being observed in the animal fed at $1.6 \times$ maintenance (Fig. 5(c)). This resulted in a significant time $x$ intake interaction $(P<0.05)$ with evidence that the quadratic response differed among times $(P<0.05)$. There was also a significant $(P=0.051)$ quadratic response to intake and a significant $(P<0.001)$ overall effect of time.

Plasma insulin concentrations increased with level of intake and in response to $\mathrm{GH}$, resulting in a significant overall effect of intake $(P=0.013)$ with a strong linear $(P=0.006)$ trend. Basal plasma concentrations (i.e. before $\mathrm{GH})$ were 3-4-fold lower in the two animals fed at near maintenance compared with those fed at higher intakes and concentrations appeared to plateau at intakes above $2.0 \times$ maintenance (Fig. 5(a)). There was no immediate response to $\mathrm{GH}$ (within $3 \mathrm{~h}$; Fig. 5(b)) but all animals showed increases in plasma insulin concentration at the time of the second flux measurement $(+2$ to $+16 \mu \mathrm{U} / \mathrm{ml}$; Fig. $5(\mathrm{c})$ ) resulting in a significant $(P<0.001)$ overall effect of time. Although the response to $\mathrm{GH}$ was smallest in the most poorly-fed animal, no time $x$ intake interaction was detected.

Basal plasma glucose concentrations were relatively constant across intake levels, ranging only from $4.4 \mathrm{mmol} / 1$ (at $0.8 \times$ maintenance) to a maximum of $5 \mathrm{mmol} / 1$ at all intakes above $1.2 \times$ maintenance (Fig. 5(a)). All animals showed an increase in plasma glucose concentration in response to $\mathrm{GH}$ at the time of the second flux measurement (Fig. 5(c)) but there was no immediate response (within $3 \mathrm{~h}$; Fig. 5(b)). Overall there was a significant effect of intake $(P=0.066)$ with both linear $(P=0.065)$ and quadratic trends $(P=0.073)$ which appears to be due to the fact that average plasma concentrations increased with increasing intake up to $2.4 \times$ maintenance but were slightly lower in the animal fed at the highest intake level. There was a significant time effect $(P<0.001)$ indicating that the average concentration differed between the three different time intervals, but no significant time $x$ intake interactions were detected. 

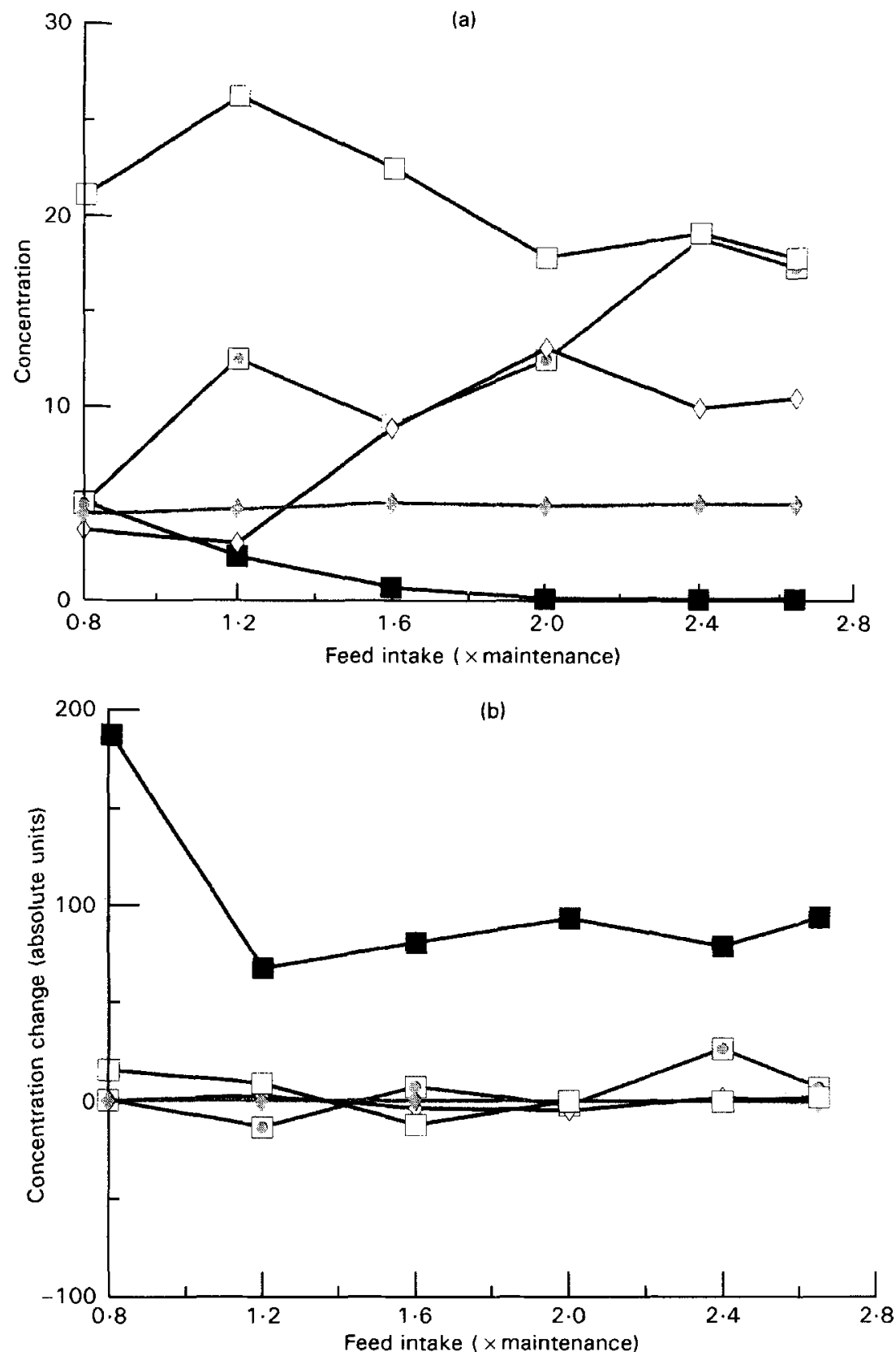

Fig. 5. Effect of feed intake on plasma growth hormone (GH; $\mathbf{C} ; \mathrm{ng} / \mathrm{ml})$, insulin-like growth factor-1 (IGF-1; 0 ; $\mathrm{ng} / \mathrm{ml}\left(\times 10^{-1}, \mathrm{panel}(\mathrm{a})\right)$, insulin $(\diamond ; \mu \mathrm{Units} / \mathrm{ml})$, glucose $(\diamond ; \mu \mathrm{mol} / \mathrm{ml})$ and urea $\left(\square ; \mu \mathrm{g} / \mathrm{ml}\left(\times 10^{-1}\right.\right.$, panel $\left.(\mathrm{a})\right)$ concentrations and the change in concentration in response to $\mathrm{GH}$ administration in cattle. Values are for one animal fed at each feed intake level between 0.8 and $2.65 \times$ maintenance. Blood samples were taken from each animal at hourly intervals and mean concentrations of hormones and metabolites were then calculated for the following three time intervals: (a) before $\mathrm{GH}$ administration, (b) $1-3 \mathrm{~h}$ and (c) 22-24 $\mathrm{h}$ after $\mathrm{GH}$ administration ( $\mathrm{n} 3$ at each period). Standard errors of difference for comparing between intakes ( $3 \mathrm{df}$ ) were $15.7,50.4,1.90,0.21$ and 27.8 for $\mathrm{GH}, \mathrm{IGF}-1$, insulin, glucose and urea respectively, and for comparing times within intake $(6 \mathrm{df})$ were $25.9,27.5,3 \cdot 15,0.20$ and 26.8 respectively.

Basal plasma urea concentrations tended to be higher in the low intake animals and to decrease linearly $(P=0.081)$ with increasing feed intake. Following administration of $\mathrm{GH}$, animals on the two lowest intakes showed small increases in plasma urea concentration $(+9$ to $+15 \mu \mathrm{g} / \mathrm{ml}$ 1-3 $\mathrm{h}$ post-administration) but there was little response at higher intakes. At the time of the second flux measurements however (22-24 h post-administration) all animals showed a reduction in plasma concentration $(-32$ to $-118 \mu \mathrm{g} / \mathrm{ml})$. This gave rise to a significant $(P<0.001)$ overall effect of time, indicating that there were differences in the average urea concentrations at the different time intervals but no time $\times$ intake interactions were detected indicating that the response showed a similar pattern with intake,

\section{Discussion}

These results demonstrate the marked influence that plane of nutrition has on amino acid and fatty acid metabolism in 


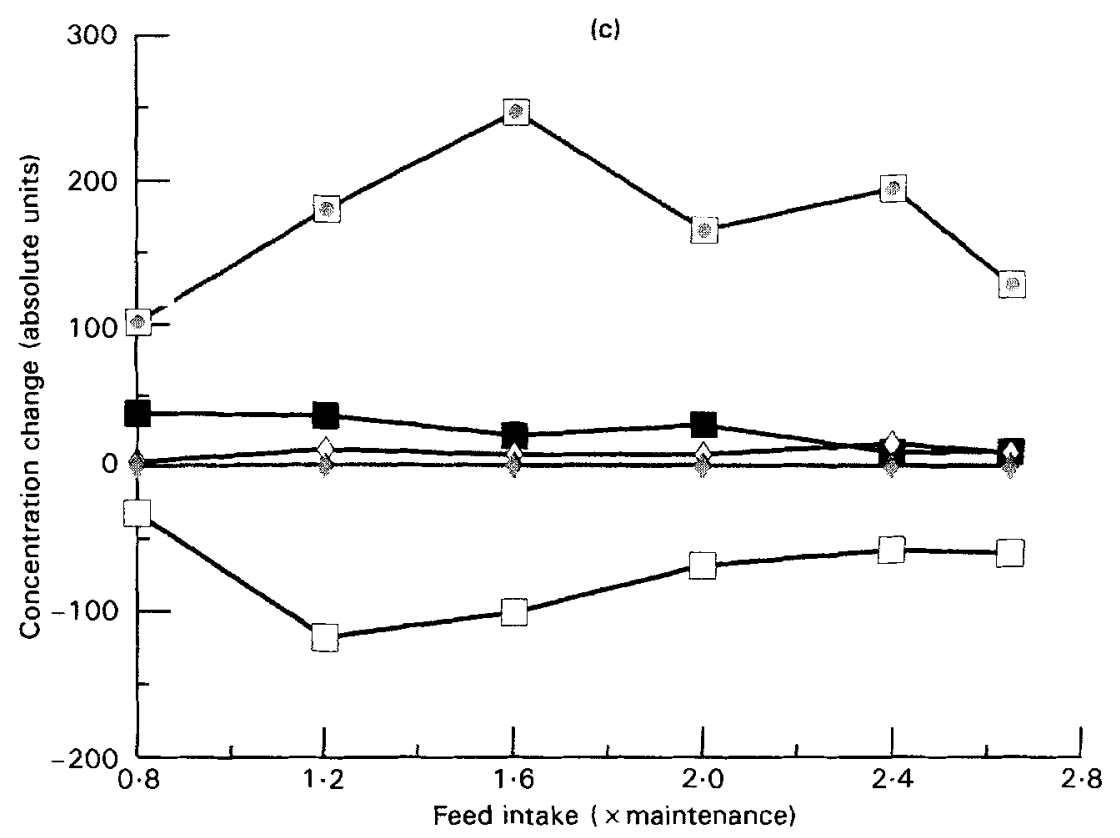

Fig. 5 (continued)

growing cattle and on the response to exogenous $\mathrm{GH}$ administration; palmitate was used as a representative fatty acid to follow whole-body lipid flux while leucine was used to determine the turnover of a typical essential amino acid. Most studies have considered only extremes of nutritional status (i.e. fed and fasted states; e.g. Crompton \& Lomax, 1993) and have considered only the response to chronic endocrine manipulation. In the present study, individual animals were fed at a range of feeding levels from just below maintenance $(0.8 \times)$ to effectively ad libitum $(2.65 \times$ maintenance $)$ and were challenged with a single subcutaneous injection of $\mathrm{GH}$, the response being assessed by fitting linear and quadratic trends to the intake data. This approach assumes that the pool size remains stable and unchanged between treatments.

\section{Effect of nutritional status on whole-body protein and lipid metabolism}

Plasma flux rates of palmitate were observed to be highest and those of leucine were lowest in the two most poorly-fed animals suggesting that these animals were mobilizing more fat and depositing less protein than animals receiving an adequate level of nutrition. These animals lost weight during the experimental period and displayed the typical endocrine response of nutritionally-deprived animals with elevated plasma GH and reduced plasma IGF- 1 concentrations compared with the well-fed animals (Breier et al. 1986). Plasma insulin and glucose concentrations were also lower in these animals. Similar responses have been observed in nutritionally-restricted cattle by other workers (e.g. Mills et al. 1989; Smith et al. 1992). Low plasma insulin and IGF-1 concentrations would be expected to induce low rates of protein synthesis and possibly increased rates of protein breakdown (Lobley, 1992). This was indicated by the low flux and plasma concentration of leucine observed in these animals, while plasma urea concentrations were elevated. Reduced plasma insulin concentrations may also increase fat mobilization, as indicated by increased palmitate flux and plasma NEFA concentrations, to provide the most poorly-fed animals with alternative metabolic fuels for maintenance functions. Plasma NEFA concentrations have been shown to correlate positively with NEFA flux rates and with rates of NEFA oxidation to $\mathrm{CO}_{2}$, and negatively with net energy balance in both growing and lactating cattle (Eisemann et al. 1986; Bauman et al. 1988) suggesting that tissue utilization of NEFA increases with increasing plasma NEFA concentration.

Effect of nutritional status on the endocrine and metabolite
responses to growth hormone

Chronic administration of GH has been shown to increase protein accretion and reduce fat deposition in a variety of species but the magnitude of the response appears to vary according to the nutritional status of the animal (see National Research Council, 1994). In the present study animals were challenged with a single subcutaneous injection of GH. The acute response to GH (within $3 \mathrm{~h}$ of administration) was restricted to an immediate rise in plasma GH concentration in all animals and an acute lipolytic response in the sub-maintenance-fed animal. Significant changes in both kinetic measurements and in plasma hormone and metabolite concentrations occurred after the peak in circulating GH concentrations (approximately $3 \mathrm{~h}$ after administration) and these varied in magnitude depending on intake level. Dunshea et al. (1992) monitored the temporal response of circulating hormones and metabolites following intramuscular administration of GH to well-fed pigs and observed similar 
responses after the first injection to those observed in the present study. However, in contrast to the study of Dunshea et al. (1992), and presumably due to the larger dose of GH administered $(0.55 \mathrm{mg} / \mathrm{kg}$ body weight compared with $0.12 \mathrm{mg} / \mathrm{kg}$ ), in the present study plasma $\mathrm{GH}$ concentrations were still elevated in all animals $24 \mathrm{~h}$ after administration. This effect was increasingly apparent at lower feed intakes and suggests that metabolic clearance of $\mathrm{GH}$ was reduced in nutritionally-deprived animals which is consistent with other reports and possibly due to increased $\mathrm{GH}$ binding protein which increases GH half-life (see Bass et al. 1992). It should be noted that the animals in the present study were fed at their assigned intake levels for 3 weeks and these nutritional treatments resulted in a $27.5 \mathrm{~kg}$ difference in live weight by the end of this period. Although this was probably largely due to gut fill, there were possibly also some changes in body composition and consequently the relationship between animals and $\mathrm{GH}$ may not only be dependent on level of nutrition but also body composition.

\section{Effect of growth hormone on lipid metabolism}

While the anabolic effects of GH on protein are believed to be mediated by IGF-1, the effects of GH on adipocytes are thought to be mediated by $\mathrm{GH}$ itself because although $\mathrm{GH}$ stimulates IGF-1 mRNA expression and secretion in adipose tissue (Coleman et al. 1994; Brameld et al. 1996), the adipocytes themselves apparently lack IGF-1 receptors (Vernon \& Flint, 1989).

GH administration increased plasma palmitate flux rates and plasma NEFA concentrations in all animals $18-24 \mathrm{~h}$ after administration indicating increased lipolysis. Similar results were reported by Eisemann et al. (1986) in growing heifers fed at just above maintenance in response to GH. In the present study the temporal response to GH differed with intake, with the animal fed below maintenance responding more rapidly (within $3 \mathrm{~h}$ of administration) than the animals at higher intakes where a response was not seen until the second infusion of tracer $(22-24 \mathrm{~h}$ post-GH). Other workers have found that the biological effects of $\mathrm{GH}$ on lipid metabolism are chronic rather than acute (e.g. Bauman et al. 1988). The effect of GH on lipolysis (palmitate flux and plasma NEFA concentration) was markedly suppressed in animals fed at the highest intake levels. This may be due to reduced $\mathrm{GH}$ receptor number as recent work has shown that $\mathrm{GH}$ receptor expression is decreased in adipose tissue and muscle of GH-treated pigs receiving a high (compared with a low) dietary protein intake, whereas expression in liver increases with intake (Brameld et al. 1996). Other studies have reported increases in plasma NEFA concentrations in response to $\mathrm{GH}$ in cattle fed at restricted intakes but not in animals given an adequate level of nutrition (Eisemann et al. 1986; Peters, 1986; McShane et al. 1989). Thus, GH has been suggested to stimulate lipolysis only when animals are fed at maintenance or are in negative energy balance. In animals in positive energy balance, GH has been shown to decrease lipid accretion mainly through a reduction in lipogenesis (Bauman \& Vernon, 1993) which has been associated with decreased sensitivity to insulin. In the present study the greatest increase in plasma NEFA concentrations in response to $\mathrm{GH}(22-24 \mathrm{~h}$ post-administration) occurred in animals fed at 1.6 and $2.0 \times$ maintenance suggesting that lipolysis was also stimulated in these animals which were in positive energy balance. The animal in most negative energy balance $(0.8 \times$ maintenance $)$, however, responded much more rapidly to the lipolytic stimulus. This effect was unlikely to be merely a consequence of the length of time this animal had been maintained at sub-maintenance level of feeding as this animal received the palmitate infusion before the leucine infusion (i.e. after 2 weeks of feeding at this level). The increased plasma NEFA concentration in response to GH presumably reflects increased tissue utilization of NEFA as an energy source (Bauman et al. 1988) thus sparing oxidation of other metabolites such as amino acids, and enabling muscle mass to be conserved, even in poorly-fed animals.

\section{Effect of growth hormone on protein metabolism}

The protein anabolic effects of $\mathrm{GH}$ are believed to be largely mediated by IGF-1. Circulating concentrations of IGF-1 have been shown to increase in response to $\mathrm{GH}$ treatment in many species but nutrition appears to modulate this response. Severe feed restriction has been shown to abolish any response to $\mathrm{GH}$ in growing cattle and lambs (Breier et al. 1988; Elsasser et al. 1989; McGuire et al. 1995). This has been suggested to be associated with the hepatic response to $\mathrm{GH}$ whereby under conditions of nutritional deprivation, hepatic $\mathrm{GH}$ receptor homo-dimerization (which gives rise to the high-affinity binding site and initiates signal transduction) fails to occur resulting in low IGF-1 production (see Breier \& Sauerwein, 1995). Whether dietary energy or dietary protein concentration is the more important factor for ensuring coupling of the $\mathrm{GH}$ IGF-1 axis is still uncertain. In the present experiment, total plasma IGF-1 concentrations were increased in response to $\mathrm{GH}$ at all intake levels. This was a little surprising but was possibly a consequence of the large dose of $\mathrm{GH}$ administered $(0.55 \mathrm{mg} / \mathrm{kg}$ body weight) (see Breier \& Sauerwein, 1995). Alternatively, the fact that the animals in the present study were fed hourly, rather than once or twice daily as in most other studies may have resulted in a more continuous supply of nutrients sufficient to maintain this axis coupling. Nevertheless, plasma concentrations of IGF1 remained considerably lower in the sub-maintenance-fed animal, even $22-24 \mathrm{~h}$ after $\mathrm{GH}$ administration, compared with animals fed at higher intake levels. Breier et al. (1988) reported that in cattle fed at a low plane of nutrition ( $1 \%$ body weight/d), approximately equivalent to the lowest intake in the present study, the IGF- 1 response to exogenous $\mathrm{GH}(0.1 \mathrm{mg} / \mathrm{kg})$ was completely abolished. However, McGuire et al. (1995) showed that the IGF-1 response was depressed but not abolished in moderately undernourished lactating cows receiving $80 \%$ of their requirements and only completely abolished with severe undernutrition ( $2 \mathrm{~d}$ feed deprivation). Although the liver is believed to be a major source of circulating IGF-1 there is 
also debate about the importance of locally produced IGF-1 in mediating the anabolic response of GH. Most IGF-1 in the circulation is bound to specific binding proteins and these may also be sensitive to level of nutrition which in turn may influence circulating IGF-1 concentrations or the availability of IGF-1 to the tissues (see McGuire et al. 1992,1995 ). There is evidence that single high doses of $\mathrm{GH}$ acutely down-regulate the high-affinity hepatic GH receptors (Maiter et al. 1988) whereas chronic treatments with GH causes up-regulation of these receptors (Sauerwein et al. 1991). This suggests that there may be differences between acute and chronic responses to $\mathrm{GH}$ and these may be influenced by nutritional status.

In the present study, administration of $\mathrm{GH}$ had no immediate effect on plasma leucine flux rate nor on plasma leucine concentrations at any intake level. In animals fed up to $2 \times$ maintenance, there was also no change in leucine flux rate $22-24 \mathrm{~h}$ after $\mathrm{GH}$ administration although plasma leucine concentrations were significantly reduced at this time. The reduction in plasma amino acid concentration in response to $\mathrm{GH}$ may be associated with the increased plasma insulin concentrations (Tesseraud et al. 1993) and may explain why the reduction in plasma leucine concentration was relatively greater in the animals fed at the highest intakes compared with the poorly-fed animals. A decrease in plasma leucine concentration with no change in flux rate as observed in animals fed up to $2 \times$ maintenance would suggest that the metabolic clearance rate must have been increased by $\mathrm{GH}$ in these animals. Chronic (14 d) $\mathrm{GH}$ treatment of both growing heifers fed slightly above maintenance and of beef steers fed at approximately $2 \times$ maintenance has also been shown to reduce the plasma concentration of leucine with no apparent effect on flux rate, but the partition of leucine flux was altered with leucine oxidation being decreased, demonstrating amino acid conservation, while leucine used for protein synthesis increased (Eisemann et al. 1986, 1989). Furthermore, while whole-body protein synthesis rates were increased by $\mathrm{GH}$, protein degradation rates were reported to be unchanged (Eisemann et al. 1986, 1989) resulting in increased wholebody $\mathrm{N}$ retention. In the present study, plasma leucine flux rates were decreased by $\mathbf{G H}$ at the two highest intake levels ( 2.4 and $2.65 \times$ maintenance), $22-24 \mathrm{~h}$ after administration. These intake levels were greater than those fed by Eisemann et al. (1989) and suggest that at high intakes, the effects of $\mathrm{GH}$ on protein oxidation may have been greater than the effect on protein synthesis, resulting in an overall decrease in plasma flux, or alternatively may indicate that protein degradation rate was reduced. Interestingly, Oddy et al. (1991) reported that IGF-1 decreased protein degradation in ovine hindlimb muscle and similar effects have been shown in ovine cultured muscle cells (Roe et al. 1989).

Reduced amino acid oxidation in response to $\mathrm{GH}$ is consistent with the observation in the present study that plasma urea concentrations were reduced by $\mathrm{GH}$ in all animals suggesting that whole-body oxidation of amino acids and the hepatic conversion of $\mathrm{NH}_{3}$ to urea was decreased. These changes in amino acid metabolism are consistent with an increased use of amino acids for protein accretion in response to $\mathrm{GH}$.
The results presented here strengthen the hypothesis that lipid and protein metabolism are differentially responsive to $\mathrm{GH}$ and nutritional status; when animals on low and high planes of nutrition were compared, those on the low plane demonstrated synergy between the response to reduced feed intake and GH treatment in terms of palmitate flux, whereas leucine flux was only decreased in response to $\mathrm{GH}$ in the animals on a higher plane of nutrition. These findings are consistent with a function for $\mathbf{G H}$ as a prime regulatory factor of lipid metabolism, whereas protein metabolism is subject to a more complex regulatory interaction between GH, IGF-1 and insulin. Indirect evidence to support this suggestion can be found in the changes in circulating $\mathrm{GH}$ and IGF-1 concentrations, which were increased maximally on low and high planes of nutrition respectively after GH administration, with insulin concentrations broadly correlating with IGF-1 concentrations. Increasing concentrations of these hormones with increasing intakes would promote tissue anabolism.

\section{Acknowledgements}

The authors are grateful to J. B. Soar and C. P. Essex for technical support and to Dr D. E. Beever for helpful discussions. We wish to thank Eli Lilley for the gift of bovine growth hormone. This work was partially funded by BBSRC. JMD also thanks OECD for a fellowship on the Biological Resource Management project and is grateful to Dr P. D. Klein for making advice and laboratory facilities available.

\section{References}

Agricultural and Food Research Council (1993) Energy and Protein Requirements of Ruminants. Wallingford: CAB INTERNATIONAL.

Bass JJ, Spencer GSG \& Hodgkinson SC (1992) Nutritional control of the growth hormone axis. In The Control of Fat and Lean Deposition pp. 175-195 [PJ Buttery, KN Boorman and DB Lindsay, editors]. Oxford: Butterworth-Heinemann.

Bauman DE, Peel CJ, Steinhour WD, Reynolds PJ, Tyrrell HF, Brown ACG \& Haaland GL (1988) Effect of bovine somatotropin on metabolism of lactating dairy cows: influence on rates of irreversible loss and oxidation of glucose and nonesterified fatty acids. Journal of Nutrition 118, 1031-1040.

Bauman DE \& Vernon RG (1993) Effects of exogenous bovine somatotropin on lactation. Annual Review of Nutrition 13, 437461.

Berthold HK, Hachey DL, Reeds PJ, Thomas OP, Hoeksema S \& Klein PD (1991) Uniformly ${ }^{13}$ C-labeled algal protein used to determine amino acid essentiality in vivo. Proceedings of the National Academy of Sciences USA 88, 8091-8095.

Brameld JM, Atkinson JL, Saunders JC, Pell JM, Buttery PJ \& Gilmour RS (1996) Effects of growth hormone administration and dietary protein intake on insulin-like growth factor-I (IGFI) and growth hormone receptor (GHR) mRNA expression in porcine liver, skeletal muscle and adipose tissue. Journal of Animal Science 74, 1832-1841.

Breier BH, Bass JJ, Butler JH \& Gluckman PD (1986) The somatotrophic axis in young steers: influence of nutritional status on pulsatile release of growth hormone and circulating concentrations of insulin-like growth factor-1. Journal of Endocrinology 111, 209-215. 
Breier BH, Gluckman PD \& Bass JJ (1988) Influence of nutritional status and oestradiol-17 $\beta$ on plasma growth hormone, insulin-like growth factors-I and -II and the response to exogenous growth hormone in young steers. Journal of Endocrinology 118, 243-250.

Breier BH \& Sauerwein H (1995) Regulation of growth in ruminants by the somatotropic axis. In Ruminant Physiology: Digestion, Metabolism, Growth and Reproduction, pp. 451-474 [W von Engelhardt, S Leonhard-Mareck, G Breves and D Giesecke, editors]. Stuttgart, Germany: Ferdinand Enke Verlag.

Coleman ME, Russell L \& Etherton TD (1994) Porcine somatotropin (pST) increases IGF-1 mRNA abundance in liver and subcutaneous adipose tissue but not in skeletal muscle of growing pigs. Journal of Animal Science 72, 918-924.

Crompton LA \& Lomax MA (1993) Hindlimb protein turnover and muscle protein synthesis in lambs: a comparison of techniques. British Journal of Nutrition 69, 345-358.

Dawson JM, Essex CP, Walsh A, Beever DE, Gill M \& Buttery PJ (1993a) Effect of fishmeal supplementation and $\beta$-agonist administration on adipose tissue metabolism in steers given silage. Animal Production 57, 397-406.

Dawson JM, Greathead HMR, Hachey DL, Reeds PJ, Buttery PJ, Pell JM \& Beever DE (1993b) The interaction between plane of nutrition and response to growth hormone on fat and protein metabolism in cattle. Proceedings of the Nutrition Society 52, $301 \mathrm{~A}$.

Digby P, Galway N \& Lane P (1989) Genstat 5, A Second Course. Oxford: Oxford Science Publications.

Douglas RG, Gluckman PD, Ball K, Breier BH \& Shaw JHF (1991) The effects of infusion of insulin-like growth factor (IGF)-I, IGF-II and insulin on glucose and protein metabolism in fasted lambs. Journal of Clinical Investigation 88, 614 622.

Dunshea FR, Bauman, DE, Boyd RD \& Bell AW (1992) Temporal response of circulating metabolites and hormones during somatotropin treatment of growing pigs. Journal of Animal Science 70, 123-131.

Eisemann JH, Hammond AC, Bauman DE, Reynolds PJ, McCutcheon SN, Tyrrell HF \& Haaland GL (1986) Effect of bovine growth hormone administration on metabolism of growing Hereford heifers: protein and lipid metabolism and plasma concentrations of metabolites and hormones. Journal of Nutrition 116, 2504-2515.

Eisemann JH, Hammond AC, Rumsey TS \& Bauman DE (1989) Nitrogen and protein metabolism and metabolites in plasma and urine of beef steers treated with somatotropin. Journal of Animal Science 67, 105-115.

Elsasser TH, Rumsey TS \& Hammond AC (1989) Influence of diet on basal and growth hormone-stimulated plasma concentrations of IGF-1 in beef cattle. Journal of Animal Science 67, 128-141.

Hachey DL, Patterson BW, Reeds PJ \& Elsas LJ (1991) Isotopic determination of organic keto acid pentafluorobenzyl esters in biological fluids by negative chemical ionization gas chromatography/mass spectrometry. Analytical Chemistry 63, 919-923.

Kriel GV, Bryant MJ \& Lomax MA (1992) Effect of dietary protein intake and intravenous glucose infusion on plasma concentrations of insulin-like growth factor-1 in lambs. Journal of Endocrinology 132, 195-199.

Lobley GE (1992) Control of the metabolic fate of amino acids in ruminants: a review. Journal of Animal Science 70, 3264-3275.

McGuire MA, Bauman DE, Dwyer DA \& Cohick WS (1995) Nutritional modulation of the somatotropin/insulin-like growth factor system: response to feed deprivation in lactating cows. Journal of Nutrition 125, 493-502.

McGuire MA, Vicini JL, Bauman DE \& Veenhuizen JJ (1992) Insulin-like growth factors and binding proteins in ruminants and their nutritional regulation. Joumal of Animal Science 70, 2901-2910.

McShane TM, Schillo KK, Estienne MJ, Boling JA, Bradley NW \& Hall JB (1989) Effects of recombinant DNA-derived somatotropin and dietary energy intake on development of beef heifers: II. Concentrations of hormones and metabolites in blood sera. Journal of Animal Science 67, 2237-2244.

Maiter D, Underwood LE, Maes M \& Ketelslegers JM (1988) Acute down regulation of the somatogenic receptors in rat liver by a single injection of growth hormone. Endocrinology 122, 1291-1296.

Mills SE, Lemenager RP \& Hortsman LA (1989) Adipose tissue lipogenesis in growing steers adapted to different levels of feed intake. Journal of Animal Science 67, 3011-3017.

National Research Council (1994) Metabolic Modifiers: Effects on the Nutrient Requirements of Food-Producing Animals. Washington: National Academic Press.

Oddy VH, Warren HM, Moyse KJ \& Owens PC (1991) IGF-1 inhibits muscle protein degradation in sheep. In 2nd International Symposium on Insulin-like Growth Factors/Somatomedins, p. 281 Abstr. San Francisco, CA: University of California.

Pell JM \& Bates PC (1992) Differential actions of growth hormone and insulin-like growth factor-1 on tissue protein metabolism in dwarf mice. Endocrinology 130, 1942-1950.

Peters JP (1986) Consequences of accelerated gain and growth hormone administration for lipid metabolism in growing beef steers. Journal of Nutrition 116, 2490-2503.

Roe JA, Harper JMM \& Buttery PJ (1989) Protein metabolism in ovine primary muscle cultures derived from satellite cells effects of selected peptide hormones and growth factors. Journal of Endocrinology 122, 565-571.

Sauerwein H, Breier BH, Bass JJ \& Gluckman PD (1991) Chronic treatment with bovine growth hormone up-regulates highaffinity hepatic somatotropic receptors in sheep. Acta Endocrinologica 12, 306-313.

Smith SB, Prior RL, Koong LJ \& Mersmann HJ (1992) Nitrogen and lipid metabolism in heifers fed at increasing levels of intake. Journal of Animal Science 70, 152-160.

Tesseraud S, Grizard J, Debras E, Papet I, Bonnet Y, Bayle G \& Champredon C (1993) Leucine metabolism in lactating and dry goats: effect of insulin and substrate availability. American Journal of Physiology 265, E402-E413.

Thissen J-P, Triest S, Moats-Staats BM, Underwood LE, Mauerhoff T, Maiter D \& Ketelslegers J-M (1991) Evidence that pretranslational and translational defects decrease serum insulin-like growth factor-1 concentrations during dietary protein restriction. Endocrinology 129, 429-433.

Tindal JS, Blake LA, Simmonds AD \& Hart IC (1985) Inhibition of growth hormone release by rumen distension in goats. Journal of Endocrinology 104, 159-163.

Vernon RG \& Flint DJ (1989) Role of growth hormone in the regulation of adipocyte growth and function. In Biotechnology in Growth Regulation, pp. 57-71 [RB Heap, CG Prosser and GE Lamming, editors]. London: Butterworth.

Winer BJ, Brown DR \& Michels KM (1991) Statistical Principles in Experimental Design, 3rd ed. New York: McGraw-Hill Inc.

Wolfe RR (1992) Radioactive and Stable Isotope Tracers in Biomedicine: Principles and Practice of Kinetic Analysis. New York: Wiley-Liss. 